\title{
八分割しわ抑え板を用いたアルミニウム板の 摩擦援用角筒深絞り加工
}

\author{
畑中 伸夫* * 末永 亮** . 飯塚 高志 $* *$ \\ 高倉 章雄 $* *$. 山口 克彦**
}

Journal of The Japan Institute of Light Metals, Vol. 62, No. 3 (2012), 109-114

\section{Friction aided deep drawing of square cups by employing a blank holder composed of eight segments}

\author{
Nobuo HATANAKA*, Ryo SUENAGA**, Takashi IIZUKA** \\ Norio TAKAKURA** and Katsuhiko YAMAGUCHI**
}

\begin{abstract}
Friction aided deep drawing has been investigated to confirm the possibility of the deep drawing of square cups. A blank holder is divided into eight segments and these segments are used instead of the conventional blank holder. These segments of the blank holder can move radically inwards and outwards depending on the blank holding pressure. When an axially punch is used together with this deep drawing process, the drawing force decreases and also the shape and dimensional accuracy can be improved. In the square deep drawing, the deformation aspect varies from portion to portion; at the punch corner and at the straight flange portion. Experimental results show that the metal flow at the corner and at the straight flange portion is approximately uniform. The square cups of $60 \mathrm{~mm}$ height, which is 2.3 times of the side length, can be obtained from a circular blank of $120 \mathrm{~mm}$ diameter and $0.5 \mathrm{~mm}$ thickness. The number of moment of radial direction of the blank holding segments was 44 times.
\end{abstract}

(Received October 13, 2011 Accepted December 17, 2011)

Keywords: deep drawing, friction aided, blank holder, aluminum sheet, square cup

\section{1. 緒言}

深絞り加工は，一枚の板材から容器形状の製品を成形する 加工法として，広く用いられている。絞り加工において，フ ランジ部の絞り変形に伴う荷重をはじめ, すべての荷重はパ ンチ肩部の材料に作用する。そのため, パンチ肩部の材料強 度が, これらの荷重の合力よりも低いと, パンチ肩部で破断 する。したがって, 1 回の絞り加工により得られる容器の深 さには限界がある。

四角筒容器の深絞り加工においては，Fig. 1に示すように, 直辺部とコーナ部で材料の変形挙動が大きく異なり，直辺部 の材料は曲げ・曲げ戻し変形を受け，コーナ部の材料は円筒 の $1 / 4$ に相当する円筒深絞り変形を受ける ${ }^{1), 2) 。 こ の た め, ~}$ コーナ半径と辺長の比が小さくなるとコーナ部の絞り変形が 厳しくなり，円筒絞り加工に比べて成形限界が小さくなる。 また，角筒絞りに固有な成形不良である成形後期のコーナ部 壁割れ ${ }^{3)}$,4) の発生や直辺部の形状不良 ${ }^{5)}$ ７）など，円筒深絞 り加工にはない多くの問題がある。これらの問題を解決し， 角筒容器の成形限界を向上させるために, その最適ブランク 形状の決定方法 ${ }^{8)}$ １1）やしわ抑え面圧の分布を制御する加工

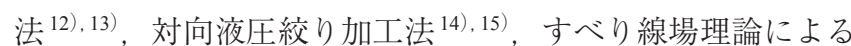
解析 $\left.\left.{ }^{11)}, 16\right) \sim 19\right)$ など数多くの研究がなされてきた。

著者らは，四分割および八分割可動式しわ抑え板を用いた 円筒深絞り加工について検討 20) 22) し, 外径 $120 \mathrm{~mm}$, 板厚 $0.5 \mathrm{~mm}$ の素板を用いて, しわ抑え板移動回数 52 回で, 成形

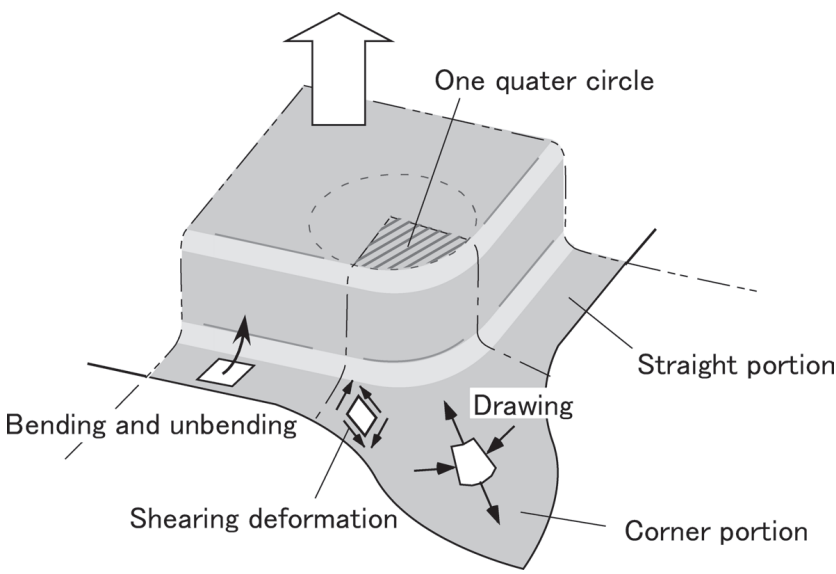

Fig. 1 Schematic diagram of deformation aspect in deep drawing of square cups.

* 鳴門教育大学 生活·健康系コース（甬772-8502 徳島県鳴門市鳴門町高島字中島748)。 Naruto University of Education (Naruto-cho, Narutoshi, Tokushima 772-8502).E-mail: nhatanaka@naruto-u.ac.jp

**京都工芸繊維大学工芸学部 (京都市)。Kyoto Institute of Technology (Kyoto-shi, Kyoto) 
高さ $74 \mathrm{~mm}$, 絞り比 4 , 成形高さとパンチ直径の比 2.47 の深 絞り加工が可能であることを示した。

本研究においては，八分割可動式しわ抑え板を使用した成 形法を，四角筒深絞り加工に適用し，その効果を検討し た ${ }^{23)}$ 。その結果，直辺部抢よびコーナ部の材料とも円滑に ダイス穴に流入させることができ，外径 $120 \mathrm{~mm}$ ，板厚 $0.5 \mathrm{~mm}$ の円形素板を用いて，しわ抑え板の移動回数 44 回で，成形 高さ $60 \mathrm{~mm}$, 成形高さとパンチ辺長の比 2.3 の四角筒容器の 深絞り成形が可能であった。

\section{2. 八分割しわ抑え板による四角筒深絞り機構}

Fig. 2 は，四角筒深絞り加工に用いた，八分割しわ抑え板 の概略を示す。Fig. 2(a) に示す四角筒深絞り加工に用いた しわ抑え板の構造は, Fig. 2(b) に示す円筒深絞り加工の場 合 ${ }^{22)}$ と比較して，中央部の穴が四角穴ダイスに合せて四角 形に変更されているが，ほかの構造は同一である。摩擦援用 深絞り加工におけるフランジ部の変形は，八分割可動式しわ 抑え板と素板との間に発生する摩擦力により行われる。パン チは，ダイス穴内に流入した材料を，ダイスに沿って引上げ る役割をするだけで，通常の梁絞り加工のように大きな荷重 を負担する必要はない。八等分したしわ抑え板のそれぞれの 下面には5 5 のテーパが付けられており，同じく上面に5゚の テーパ面が 8 面に付けられた台の上に重ね合される。これに より，各しわ抑え板が前後に移動しても，しわ抑え板の上面 はダイス面に対して常に平行が保たれる。

8 個のしわ抑え板のうち，まず，A- $\mathrm{A}^{\prime}$ 方向に位置した対向 する 1 対 (2 個) と, A-A 方向に垂直な方向の対向する 1 対 (2 個），合計 2 対（4個）のしわ抑え板（直辺部：以下，A方向 と呼ぶ）が, Fig. 2(c) に示すように，同時にテーパ台の斜 面を上り，素板とダイスを持上げながらダイス穴中心向きに 変位する。これによって，A方向しわ抑え板の上部に位置す るフランジ部の材料は, ダイス穴中心向きに移動する。一方, それらの間に挟まれた B-B'方向および $\mathrm{B}-\mathrm{B}^{\prime}$ 方向に垂直な方 向の残された 2 対 (4個)のしわ抑え板 (コーナ部：同 B方向) は，このときFig. 2(d) に示すように，後方へ押出される。 後退したしわ抑え板は，素板との接触が断たれ，しわ抑え力
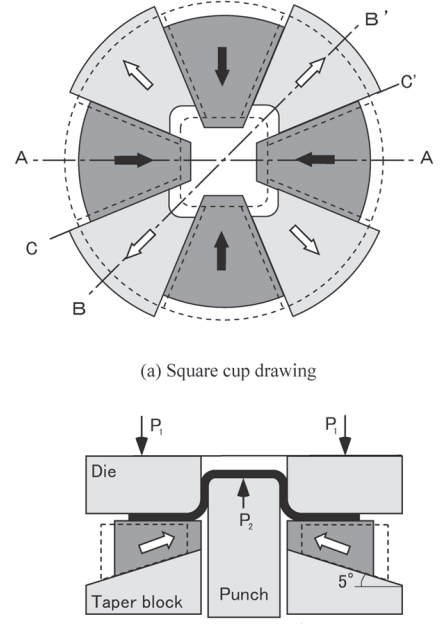

(c) Section A-A' (a) Square cup drawing

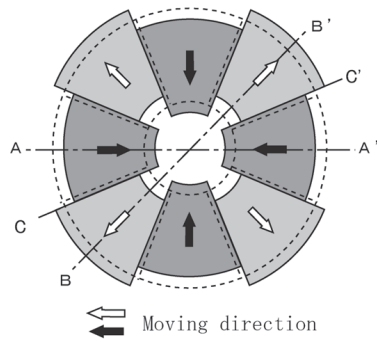

(b) Cylindrical cup drawing

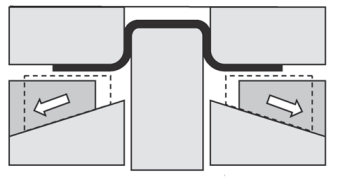

(d) Section B-B'
Fig. 2 Principle and mechanism of friction aided deep drawing using eight segments as a blank holder.
は発生しない。1回目の加工が終了後, しわ抑え板は初期位 置に戻される。次に, B方向の 2 対 (4個)のしわ抑え板がテー パ台の斜面を上り，素板とダイスを持上げながらダイス穴中 心向きに変位し，B方向のしわ抑え板の上部に位置するフラ ンジ部の材料を，ダイス穴中心向きに移動させる。このとき， A方向の2対 (4個) のしわ抑え板は, 後方へ押出され, 素 板との接触が断たれるため，しわ抑え力は発生しない。この ように八分割されたしわ抑え板を用いて，しわ抑え板の移動 操作を, A方向, B方向と交互に繰返すことにより, フランジ 部の材料は交互に中心向きに移動し, パンチの斢引力により ダイス穴内に流入することにより，深絞り加工が進行する。

\section{3. 実 験方法}

実験に使用した材料は，板厚 $0.5 \mathrm{~mm}$ の軟質純アルミニウ ム板 (A1050-O) である。材料の機械的性質を Table 1 に示す。 引張試験に使用した試験片は, 材料の圧延方向が引張軸方向 と一致するよう作製した。なお， $F, n$ 值は，一軸引張りにお ける応力ーひずみ線図を $\sigma=F \varepsilon^{n}$ で近似したものである。 $r$ 值 は，軸方向公称ひずみ 0.15 で測定した。

絞り加工に使用した試験片は，外径が $86 \mathrm{~mm}$ および $120 \mathrm{~mm}$ の円形素板である。素板には, 成形後の材料流動を 観察するために， $22.5^{\circ}$ 方向ごとに放射状および $2 \mathrm{~mm}$ 間隔に 同心円状のけがき線をいれた。なお，成形加工において材料 の圧延方向は, A方向と一致させた。

使用した工具の寸法を Table 2 に示す。ダイスの辺長 $28 \mathrm{~mm}$, コーナ半径 $3 \mathrm{~mm}$ 抢よび $5 \mathrm{~mm}$, 肩部半径 $3 \mathrm{~mm}$, パン チの辺長 $26 \mathrm{~mm}$, コーナ半径 $2 \mathrm{~mm}$ （肩部半径 $2 \mathrm{~mm}$ ） および $4 \mathrm{~mm}$ (同 $4 \mathrm{~mm}$ ) である。ダイスおよびしわ抑え板の材質は SKD11である。これらの工具が素板と接触する面の表面粗 さは, 加工に重要な影響を与えるため, 接触面は研削加工を

Table 1 Mechanical properties of material (A1050-O)

\begin{tabular}{|c|c|c|}
\hline \multicolumn{2}{|c|}{$\begin{array}{l}\text { Yield strength, } \sigma_{0.2}(\mathrm{MPa}) \\
\text { Ultimate tensile strength, } \sigma_{\mathrm{B}}(\mathrm{MPa}) \\
\text { Total elongation, } \delta(\%) \\
F(\mathrm{MPa}) \\
n \text {-value }\end{array}$} & $\begin{array}{r}30 \\
82 \\
38 \\
220 \\
0.27\end{array}$ \\
\hline$r$-value & $\begin{array}{r}0^{\circ} \\
45^{\circ} \\
90^{\circ}\end{array}$ & $\begin{array}{l}0.81 \\
1.27 \\
0.84\end{array}$ \\
\hline \multicolumn{2}{|c|}{$\begin{array}{l}\text { Blank thickness }(\mathrm{mm}) \\
\text { Blank diameter }(\mathrm{mm})\end{array}$} & $\begin{array}{c}0.5 \\
86,120\end{array}$ \\
\hline \multicolumn{3}{|c|}{$\begin{array}{l}\text { Table } 2 \text { Dimensions of punch and die used for square deep } \\
\text { drawing }\end{array}$} \\
\hline Die & $\begin{array}{l}\text { Opposite side length } \\
\text { Corner radius } \\
\text { Shoulder radius }\end{array}$ & $\begin{array}{c}28 \\
3,5 \\
3\end{array}$ \\
\hline Punch & $\begin{array}{l}\text { Opposite side length } \\
\text { Corner radius } \\
\text { Shoulder radius }\end{array}$ & $\begin{array}{l}26 \\
2,4 \\
2,4\end{array}$ \\
\hline
\end{tabular}


行い，さらにダイス表面および肩部は，ラッピング仕上げを 行った。加工後の表面粗さは，ダイス表面 Ra $0.05 \mu \mathrm{m}$ ，しわ 抑え板表面 Ra $0.2 \mu \mathrm{m}$ であった。成形加工時の潤滑状態は, 素板としわ抑え板間は無潤滑とし，素板とダイス間には白色 ワセリンとテフロンシートを併用した。加工条件は，八分割 しわ抑え板を用いた円筒深絞り加工において，最も良好な結 果が得られた条件と同一 22) とし，しわ抑え力 $100 \mathrm{kN} ， 1$ 回当 たりのしわ抑え板移動量 $1 \mathrm{~mm}$ ，パンチ荷重 $4 \mathrm{kN}$ とした。

\section{4. 実験結果と考察}

\section{1 しわ抑え板の移動回数に伴う成形高さおよび外径の 変化}

Fig. 3 は, 成形時の形状変化をしわ抑え板の移動回数 $N=10$ 回ごとに示したものである。パンチコーナ半径R2の場合で ある。また，Fig. 4 は，しわ抑え板の移動回数の増加に伴う 成形高さの変化を円筒深絞り加工の場合 ${ }^{22)}$ と比較して示し ている。成形高さはしわ抑え板の移動回数に比例して，ほほ 直線的に増加した。成形高さの増加率は，パンチによる牽引 力が同じであっても，円筒深絞りの場合に比べて，四角筒深 絞りの場合の方が小さい。また，パンチコーナ半径がR4か ら R2に小さくなると, 成形高さの増加率はさらにすこし小

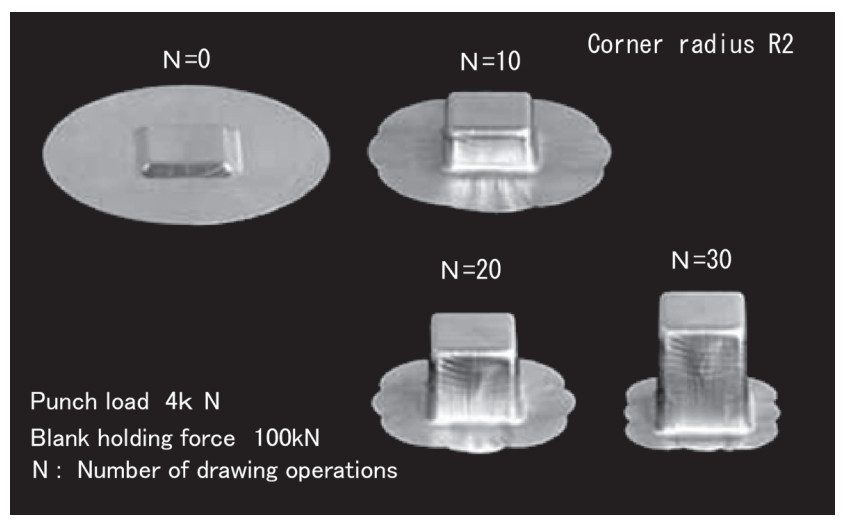

Fig. 3 Increase in cup height with number of drawing operations.

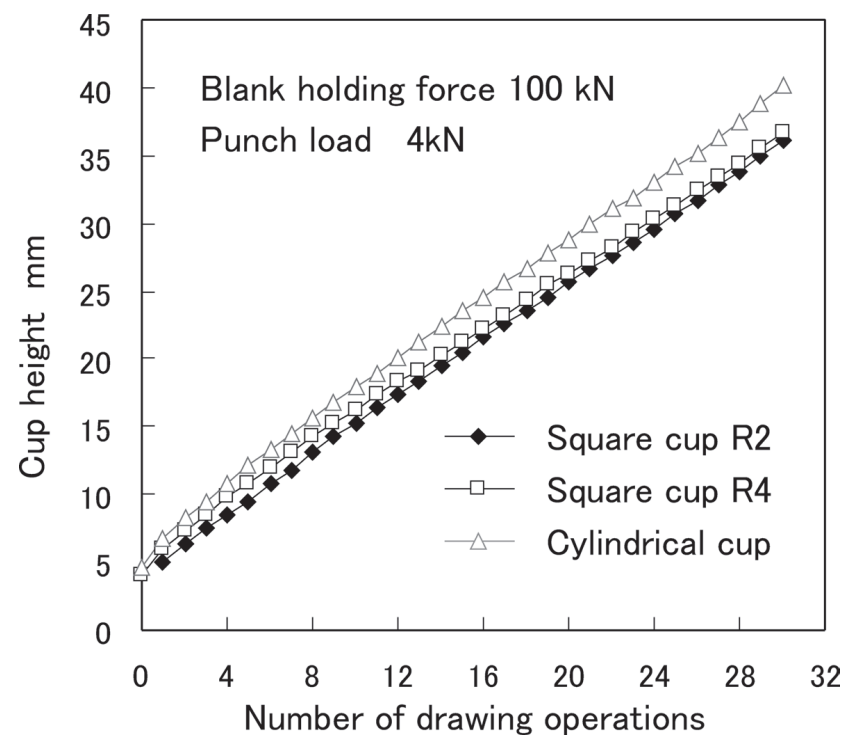

Fig. 4 Increase in height of a square cup with number of drawing operations.
さくなる。この原因は, 円筒深絞りの場合に比べ四角筒深絞 りの場合には，フランジ部からダイス穴へ流入する材料が， A方向（直辺部）では曲げ・曲げ戻し変形のみを受けるだけ で比較的多いが，B方向（コーナ部）では極めて厳しい絞り 変形を受けるため少なく，全体として少なくなるためと考え られる。さらに、コーナ半径が小さくなると、コーナ部にお ける絞り変形が一層厳しくなり，材料流入がさらに困難にな る。また，コーナ近傍の側壁部を形成するのに必要な材料が 増加するため, 成形高さの増加率が小さくなると考えられる。

Fig. 5 は，フランジ部の変形過程をしわ抑え板の移動回数 $N=10$ 回ごとに示したものである。パンチコーナ半径 R2 の場 合である。加工の進行に伴いフランジ部の外径が減少し，8 個の耳が形成されていく様子が観察される。また，Fig. 6 は, しわ抑え板の移動回数の増加に伴う外径の変化を示してい る。A方向（直辺部）では，フランジ部の材料はダイス肩部 で曲げ・曲げ戻し変形を受けるが, ダイス穴内への流入は比 較的容易であり，外径の減少率は大きい。また，A方向のし わ抑え板に荷重が加わる奇数回目の加工時に外径は大きく減 少しているが, 荷重が加わらない偶数回目にはあまり減少し

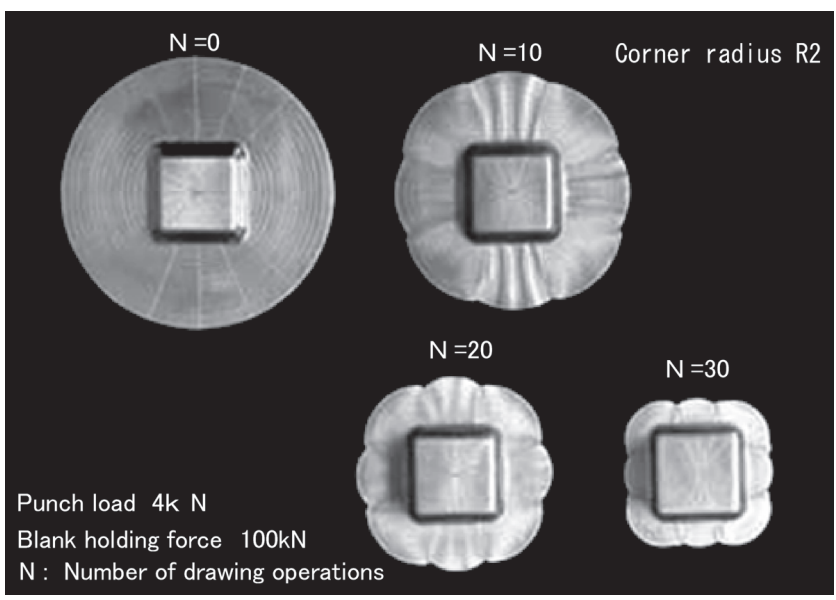

Fig. 5 Variation of flange shape in square drawing with number of drawing operations.

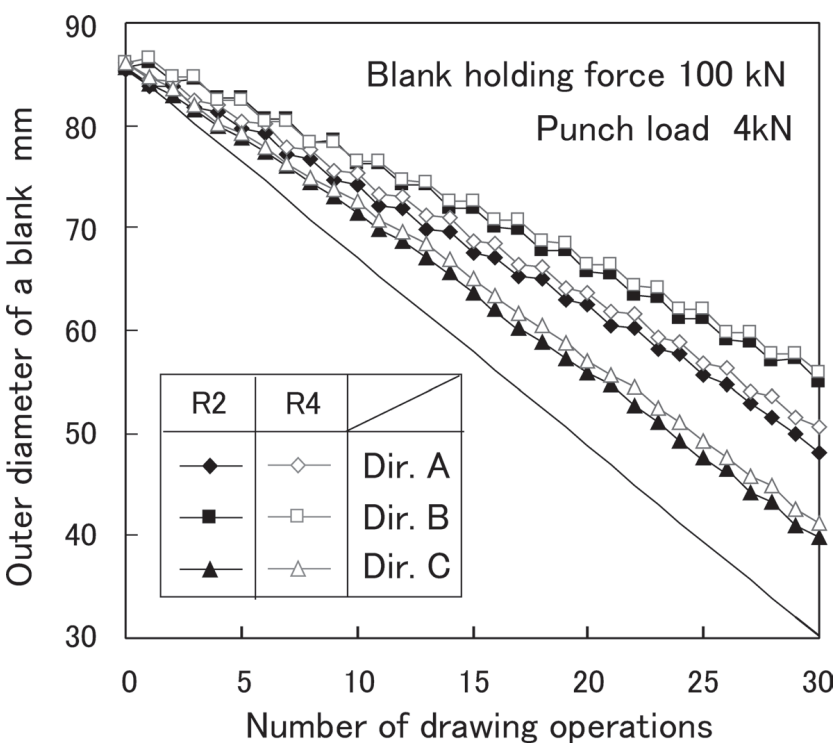

Fig. 6 Decrease in outer diameter of the blank with drawing operations. (Dir. A: Direction of A) 
ない。一方， B方向（コーナ部）では，フランジ部の材料は 絞り変形を受けるため材料の流動抵抗が大きく，ダイス穴内 への材料流入が少ないため, 外径の減少率は小さい。また, B方向のしわ抑え板に荷重が加わる偶数回目には外径は大き く減少しているが，荷重が加わらない奇数回目の加工時には ほとんど減少しない。C方向では，A方向および $\mathrm{B}$ 方向の両 方のしわ抑え板の移動時に，中心向きの力が作用するため， 外径は直線的に大きな減少を示す。また，外径変化に及ぼす コーナ半径の影響はわずかであり, 顕著な差異は認められな w。

\section{2 フランジ各部の変形状態}

フランジ各部の変形状態を検討するため, 素板に $2 \mathrm{~mm}$ 間 隔で同心円状にけがき線を入れ，Fig. 2 に示したA, Bおよび C方向について，けがき線の変位を加工1回ごとに測定した。 Fig. 7 は，しわ抑え板の移動に伴う，A方向（直辺部）のフ ランジ各部における材料の中心向き移動量の分布を示してい る。A方向のしわ抑え板をダイス穴中心向きに移動させたと き（奇数回の移動回数）には，すべての半径位置において材 料の移動量はしわ抑え板の移動量 $1 \mathrm{~mm}$ と等しくなった。一

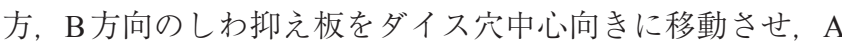
方向のしわ抑え板には荷重が加わらないとき（偶数回の移動 回数)には，材料の移動量は半径方向に大きな分布を生じた。 特に，ダイス肩付近の材料には，しわ抑え力が作用せず，ダ イス穴中心向きの荷重が作用していないにもかかわらず，約 $1.1 \mathrm{~mm}$ の大きな材料流動が生じている。この原因は, 直辺 部の材料は流動抵抗が小さく，隣接する B方向の材料流動に 伴って移動させられること，また，パンチの牽引力による材 料流入が大きいためと考えられる。

Fig. 8 は B 方向（コーナ部）のフランジ各部における材料 の中心向き変位量を示している。しわ抑え力を受けない奇数 回時の変位量は, ダイス穴付近で約 $0.5 \mathrm{~mm}$, けがき線の最 外部ではほとんど移動せず，全体として変位量は直辺部に比 べて少なくなっている。これはコーナ部の変形が絞り変形で あり, 直辺部の曲げ・曲げ戻し変形に比べ，変形抵抗が大き

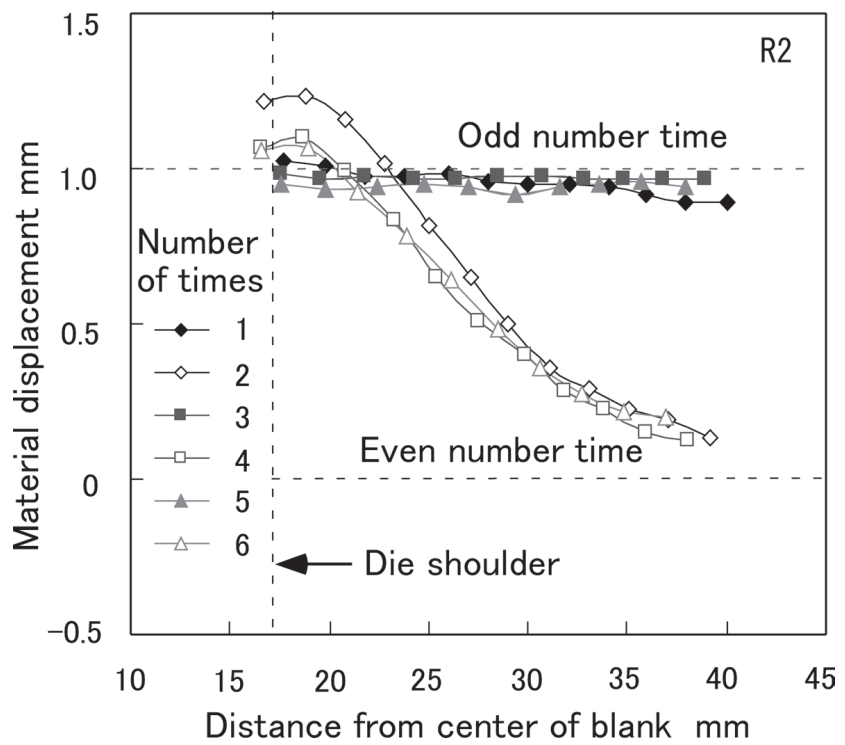

Fig. 7 Distribution of material displacement of blank material at flange portion of A-direction with distance from center of the blank.
いためと考えられる。一方, B方向のしわ抑え板をダイス穴 中心向きに移動させたときには（偶数回の移動回数）, すべ ての半径位置で材料の移動量はしわ抑え板の移動量 $1 \mathrm{~mm}$ と 等しくなった。

Fig. 9 は，しわ抑え板の境界方向（C方向）における材料 の中心向き移動量を示している。しわ抑え板の移動回数に関 係なく，ほほ同じ移動量を示している。移動量は，しわ抑え 板の境界方向における移動量のダイス穴中心向き成分, $1 \mathrm{~mm} \times \cos 22.5^{\circ}=0.92 \mathrm{~mm}$ とほぼ一致している。

パンチのコーナ半径を R4にした場合，AおよびC方向の 材料の移動量は，R2の場合とほとんど変わらなかった。し かし，B方向ではR2の場合に比べて，しわ抑え力を受けな い回数時のダイス肩付近で変位量が少し増加した。これは, R4の場合にはコーナにおける絞り変形が相対的に容易なた

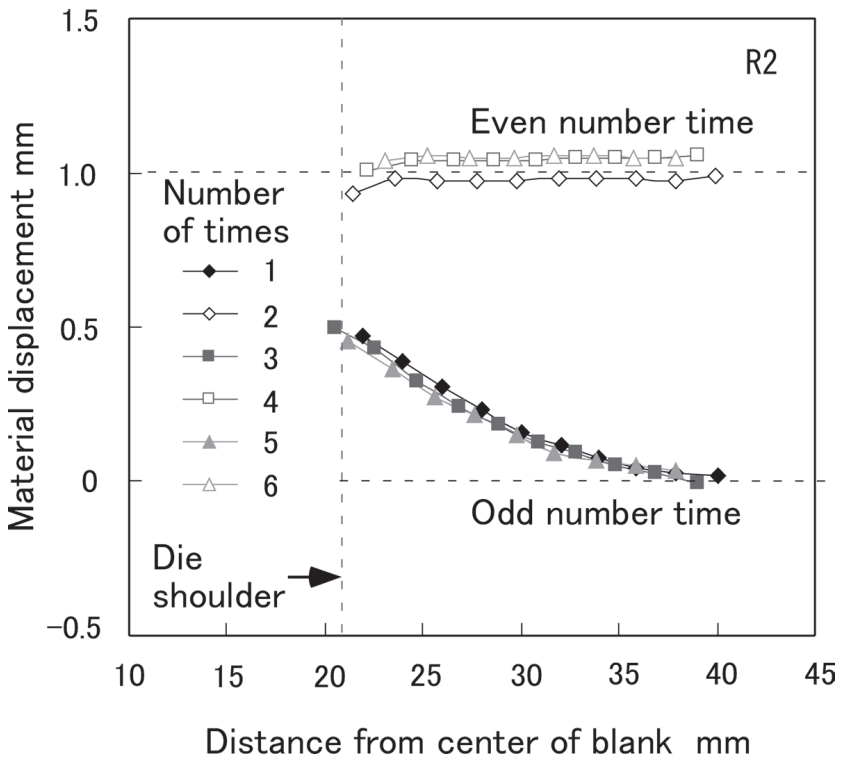

Fig. 8 Distribution of material displacement of blank material at flange portion of B-directions with distance from center of the blank.

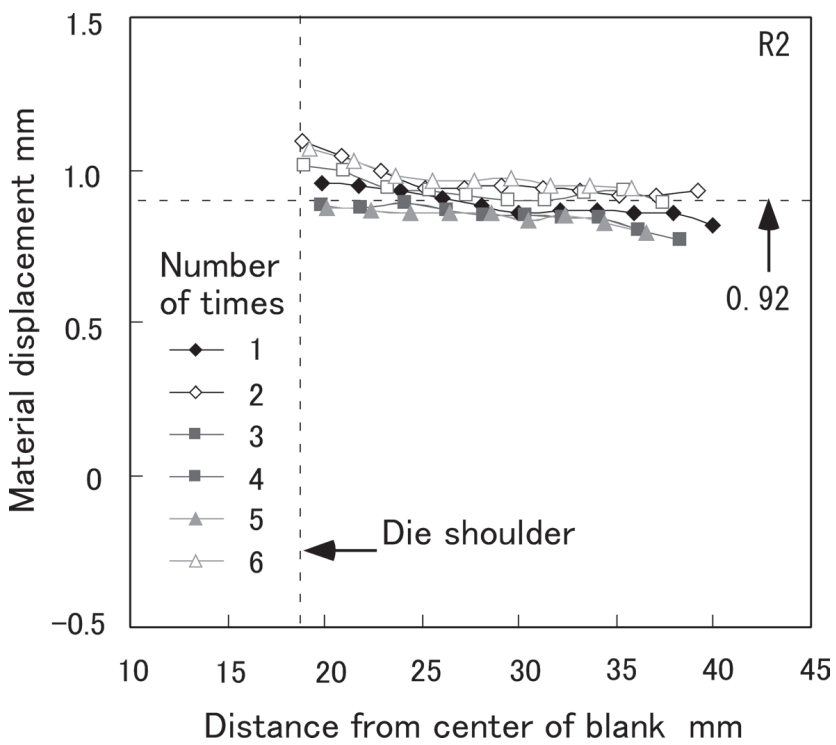

Fig. 9 Distribution of material displacement of blank material at flange portion of $\mathrm{C}$-directions with distance from center of the blank. 


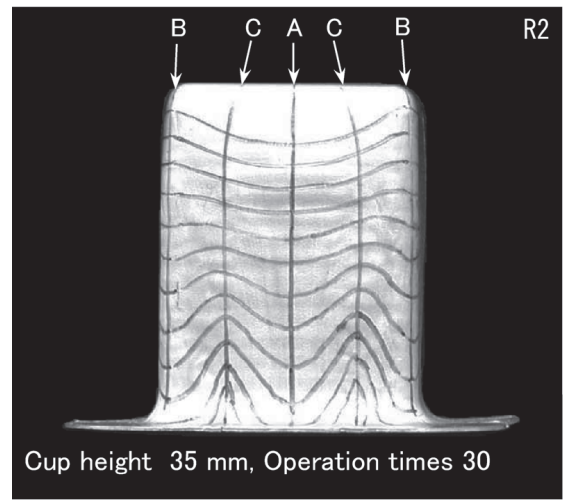

(a) Corner radius $\mathrm{R}=2 \mathrm{~mm}$

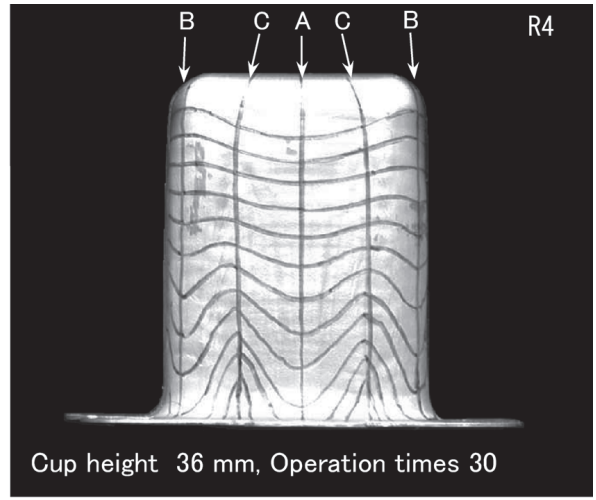

(b) Corner radius $\mathrm{R}=4 \mathrm{~mm}$

Fig. 10 Material flow at side wall of square cups.

めである。

\section{3 側壁部の変形状態}

Fig. 10 は，成形前 $2 \mathrm{~mm}$ 間隔であった同心円状のけがき線 と, $22.5^{\circ}$ ごとにけがいた放射状のけがき線の成形後の形状 例を示している。Fig. 10（a) は，パンチコーナ半径 $2 \mathrm{~mm}$ の 場合, Fig. 10(b) は同 $4 \mathrm{~mm}$ の場合である。コーナ半径の違 いによる，成形後のけがき線の形状に大きな差異はない。

放射状のけがき線は，いずれの場合も成形後に側壁部でほ ぼ平行になった。すべり線場理論による四角筒容器の絞り加 工の解析 ${ }^{16)}$ 19) によれば，フランジ部の材料は最大主応力 線に沿って流動するとされている。このため，成形前に放射 状のけがき線は，通常の四角筒深絞り加工後には平行になら ない。しかし，Fig. 10 に示すように，本成形法ではけがき線 は成形後にほぼ平行であることから，コーナ部からしわ抑え 板境界線（Fig. 2のC方向）を越えて直辺部へ流出する材料 は，通常の四角筒絞り加工の場合に比べ少ないと考えられ る。この理由は, 本加工法ではしわ抑え板による材料のダイ ス穴への流入が，コーナ部と直辺部で交互に独立して行われ るためである。

同心円状のけがき線の間隔は，3方向の中で $\mathrm{C}$ 方向が増減 なく均一に最も狭くなっている。A方向の間隔ははじめ狭い が, 加工の進行に伴って広がっている。B方向の間隔ははじ めからやや広く, 加工の進行に伴ってさらに広くなってい る。けがき線の間隔はダイス肩からの材料供給が多いと狭 く，少ないと広くなると考えられる。

C方向においては，Fig. 6 に示したように成形に伴う外径 の減少率が最も大きく, Fig. 9 に示したダイス肩近傍におけ る材料の移動量が奇数回と偶数回（例えば，第 1 回目と第 2 回目）を合せると約 $1.8 \mathrm{~mm}$ と大きく，多くの材料がダイス穴 内へ流入することから，けがき線の間隔が狭くなると考えら れる。B方向では, Fig. 6 の外径減少率が一番小さく, Fig. 8 に示したダイス肩近傍の材料の移動量が奇数回と偶数回を合 せて約 $1.5 \mathrm{~mm}$ と小さく，材料流入が少ないことから，けがき 線の間隔が広くなると考えられる。一方, A方向では, Fig. 6 の外径減少率は $\mathrm{B}$ 方向と $\mathrm{C}$ 方向の中位にあり，けがき線の間 隔と定性的に一致している。しかし，Fig. 7に示したダイス 肩近傍の材料の変位は, 奇数回と偶数回を合せると約 $2 \mathrm{~mm}$ と最も大きく，けがき線の間隔が最も狭くなるはずである が，C方向の方が狭くなっている。この原因を明らかにする には,さらに詳細な検討が必要であるが，今後の課題とする。

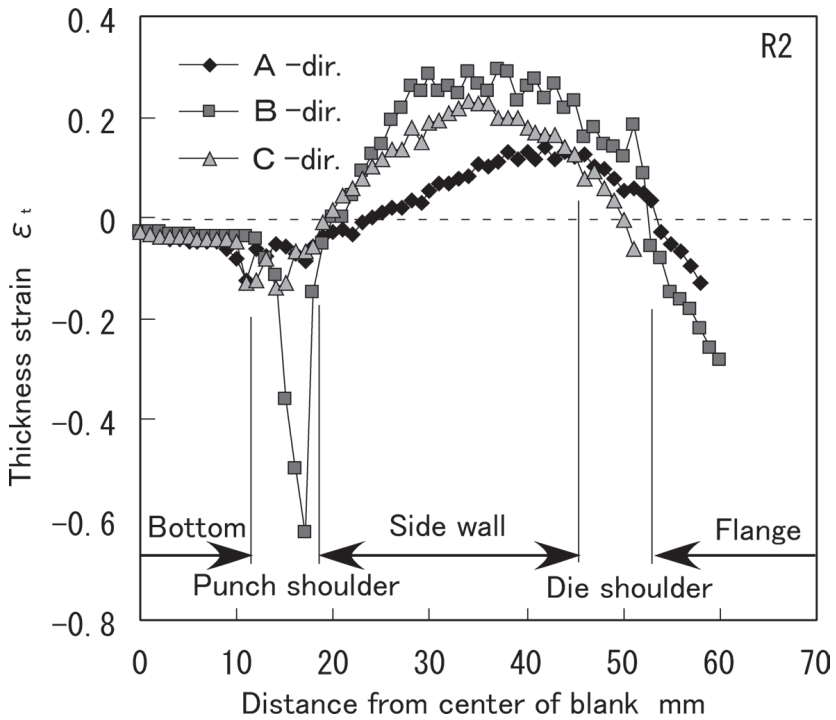

Fig. 11 Thickness strain distribution of drawn cups.

\section{4 成形品の板厚ひずみ分布}

Fig. 11 は, 四角筒容器成形後の各方向における公称板厚ひ ずみ分布を示す。コーナ半径R2の場合である。なお，容器 底部中央からパンチ肩部およびダイス肩部までの長さは, 方 向によって異なり，A方向では 10〜 13 mm および 46〜 $50 \mathrm{~mm}$, B方向では 15〜 $18 \mathrm{~mm}$ および 51〜 55 mm, C 方向では 13〜 $15 \mathrm{~mm}$ および49〜 $53 \mathrm{~mm}$ である。図より，パンチ頭部では， 板厚の減少はほとんどない。パンチ肩部では，ダイス穴に流 入した材料をパンチが率引するため, パンチ肩部の材料に荷 重が局所的に加わり，板厚が減少している。この傾向は特に， B方向（コーナ部）において著しい。

側壁部ではすべての方向において，板厚が増加している。 この原因は，フランジ部における絞り変形により，材料は周 方向に圧縮されるが，半径方向への材料流動が少ないため に，材料が余剩となり板厚の増加が生じると考えられる。ま た， A方向（直辺部）よりも B 方向（コーナ部）の方が, 大 きな絞り変形を受けることおよび半径方向の材料流動が少な いことから，板厚の増加が大きくなっている。直辺部におい ても板厚が増加しているが，この原因はコーナ部近傍におけ る厳しい絞り変形を緩和するように，材料がコーナ部からし わ抑え境界線を越えて直辺部に流入するためである。

一方，B方向の側壁部には，板厚の細かな増減がみられる。 


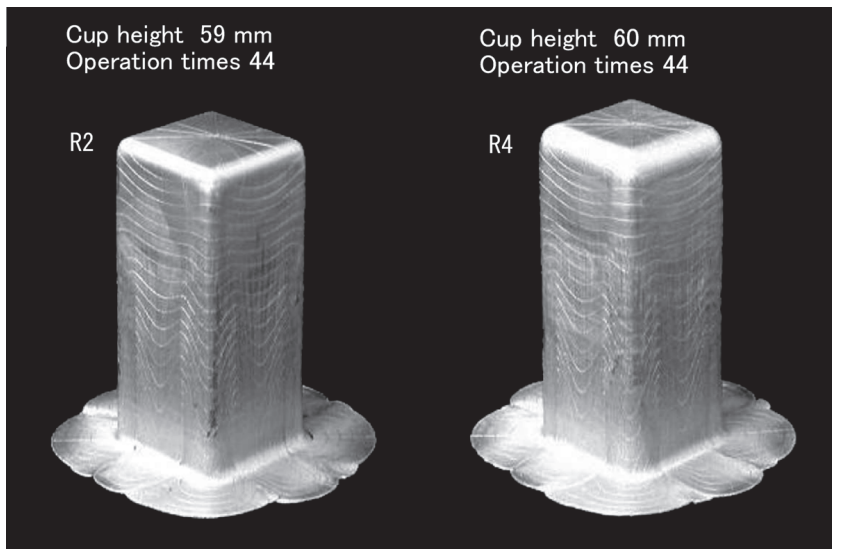

Fig. 12 Typical example of square cups.

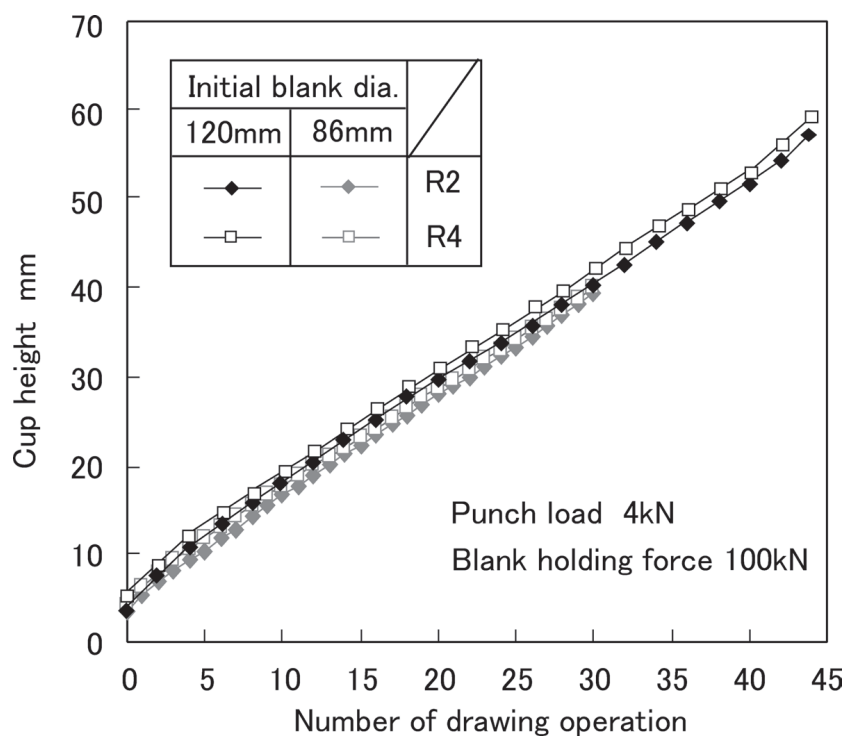

Fig. 13 Effect of initial blank diameter on cup height.

この原因は，材料がダイス肩部を通過するときの変形条件の 違いにより生じると考えられる。すなわち，しわ抑え力によ る圧縮を受けながらダイス穴内に流入するときには，材料は しわ抑え板により板厚方向に拘束されているため, 板厚の増 加は少ない。一方，しわ抑え力を受けないときには，絞り変 形により板厚が増加した状態で，材料がダイス穴内に流入す るために大きくなる。なお，コーナ半径R4の場合も同様な 結果となった。

\section{5 深い容器の成形品例}

Fig. 12 は, 外径 $120 \mathrm{~mm}$ の円形素板を用いた四角筒容器の 成形品例である。しわ抑え板の移動回数 44 回で, コーナ半 径R2の場合には成形高さ $59 \mathrm{~mm}$, コーナ半径 R4の場合には 成形高さ $60 \mathrm{~mm}$ の四角筒容器を成形することができた。これ らはパンチ辺長の約 2.3 倍に相当する。また，Fig. 13 は，加 工回数の増加に伴う成形高さの変化を示している。成形高さ は，外径 $86 \mathrm{~mm}$ の円形素板を用いた場合とほぼ同じ傾きで, 直線的に増加している。

\section{5. 結言}

可動式八分割しわ抑え板を用いた摩擦援用深絞り加工を四 角筒容器の成形に適用し, 加工中の材料流動や材料各部の変 形挙動を観察し，深絞り性の向上について検討した。その結
果，以下の知見を得た。

（1）八分割しわ抑え板を用いた摩擦援用四角筒深絞り加工 において，パンチ肩部の材料に大きな荷重を加えることな く，分割しわ抑え板を交互に移動させることにより，直辺部 およびコーナ部の材料を，円滑にダイス穴に流入させること ができた。

（2）しわ抑え板の移動に伴って，しわ抑え力が加わってい るフランジ部の材料は，しわ抑え板とほぼ同じだけ移動をす る。一方，しわ抑え力が加わっていない側の材料は，全体的 にはダイス穴中心向きに移動するが，ダイス穴近傍におい て，直辺部ではしわ抑え板移動量とほぼ同じだけ移動する が，コーナ部では約 50\%の移動にとどまる。

（3）本成形法においては，コーナ部の材料が直辺部に流出 することはなかった。また，側壁部の板厚は直辺部，コーナ 部および境界部ともに増加するが，肉余りにより成形が妨げ られることはなかった。

（4）外径 $120 \mathrm{~mm}$, 板厚 $0.5 \mathrm{~mm}$ の円形素板を用いて, しわ 抑え板の移動回数 44 回で, 成形高さ $60 \mathrm{~mm}$, 成形高さとパ ンチ辺長の比 2.3 の四角筒容器の深絞り成形が可能であった。

本研究は, 財団法人金型技術振興財団および公益財団法人 軽金属奨学会による研究助成により実施されました。記し て，ここに謝意を示します。

\section{参 考 文 献}

1）平岩正至，近藤一義：日本機械学会論文集 C編，49（1983）695703

2）日本塑性加工学会：プレス絞り加工, 日本塑性加工学会, コロ ナ社, (1994)，46-48.

3）岡本豊彦，林 豊：塑性と加工， 7 (1966)， 584-593.

4）林 豊：塑性と加工, 10 (1969)，422-432.

5）高橋 進, 桑原利彦, 伊藤健治：塑性と加工，37 (1996), 13601366

6）桑原利彦, 市川裕之, 田中芳郎：平成 2 年度塑性加工春季講演 会講演論文集, (1990)，41-42.

7）広瀬洋三, 菱田祐次, 佐藤信一：第45 回塑性加工連合講演会 講演論文集，（1994），343-344

8）福井伸二, 吉田清太，阿部邦夫，堀田勇次郎：日本機械学会誌, 59 (1956)， 898-903

9）森 敏彦, 河合 望, 丸茂康男, 千賀雅明：日本機械学会論文 集 C編，53 (1987)，771-779.

10）桑原利彦：塑性と加工，35(1994)，373-378

11）桑原利彦, 司文華，秀野雅之：塑性と加工，37（1996）, 290296

12）村田篤信, 恵比根美明, 松居正夫：塑性と加工, 33 (1992)，411416.

13）桑原利彦, 増田大助, 畔柳 遵: 塑性と加工, 35 (1994), 868874

14）中村和彦, 中村正美：塑性と加工，35 (1994)，881-886

15）中村和彦：軽金属，47(1997)，323-328。

16）神馬 敬：塑性と加工, $11(1970) ， 653-660$

17）神馬 敬, 桑原利彦：塑性と加工, 31 (1990), 141-145.

18）伊倉 真, 栗山幸久, 大上哲郎：第 41 回塑性加工連合講演会 講演論文集，（1990），297-298

19）司文華，桑原利彦，秀野雅之：塑性と加工，38（1997），354-359.

20）畑中伸夫, 飯塚高志, 高倉章雄, 山口克彦, M. A. Hassan：軽 金属, 60 (2010), 315-320.

21）畑中伸夫，松浦規夫，飯塚高志，高倉章雄，山口克彦：軽金属, 60 (2010), 641-646

22）畑中伸夫, 末永 亮, 飯塚高志, 高倉章雄, 山口克彦 : 軽金属, 61 (2011), 525-531

23）末永 亮, 高倉章雄, 山口克彦, 飯塚高志: 平成 14 年度塑性 加工春季講演会講演論文集，（2002），271-272. 